\title{
AN EMPIRICAL ANALYSIS OF THE GROWTH WITH STABILITY IN INDIA
}

KEY WORDS: Stability parameters, Economic growth, CPI, WPI, CAD, GFD, FRBM Act.

\section{Dr. Kishor P.} Kadam
Assistant Professor \& Head, Department of Economics, SNDT College of Arts And Scb College of Commerce And Science For Women, Churchgate Mumbai-20

The growth rate of GDP is an indicator of the economic performance of Indian economy. In the recent time falling GDP growth rate of India is the main concern of a debates among the economist. In this study honest effort made to investigates the relationship between growth rate of GDP and stability parameters over a period of 2000-01 to 2017-18. The empirical results of the study shows that there is a positive relationship between CPI and the growth rate of GDP whereas there were negative relationship between WPI, CAD and GFD and growth rate of GDP in India. Therefore, the study suggests that FRBM Acts guidelines should have implemented very systematic and even more strictly to control the CAD and GFD.There is need of the effective new policy framework to minimize the government failure.

During the financial year 1990-91 India was suffering different economics crisis. These crises are given the major turn toward the fundamental changes in context and approach in the economic policy of India. The economic crisis makes compulsion to put a set of policies to stabilize and structural changes for Indian economy. The main aims of the stabilization polices was to correct the weakness that had generated in the fiscal as well as balance of payment. This doesn't mean that structural reforms have completely eliminated the problems in different sectors of the Indian economy.

After independence, there was dominant view on development of economics that had to pay a vital role. Even that time, the government expectation should have undertake initiatives to compensate for market failure. Therefore the role of the government in the economy is consistently increased. However, last decades developments experiences have shown that there would be government failure as well. The regulatory state in many countries has resulted in economic losses not only due to the misallocation of resources arising from faulty investment decisions but also from the diversion of resources to rent-seeking activities because of the very regulations themselves (Rangarajan, 2018). Even today after intervening the government India's growth rate of GDP steadily falling down. It means that there it doesn't matter of presence or absence of the government intervention in the economy to stabilize the economic indicators. so the growth rate of GDP would be moderate. However, development history reveals that both market failure and the government failure are seems in the Indian economy to stabilize the growth.

\section{Reviewed Literature}

Very few literatures are available in growth with stability. Probably available literature deals with single stability parameter and its effect on GDP. These studies give partial information. One appropriate description is give by $\mathbf{C}$. Rangarajan has explained the all parameter of stability and its concern on growth of Indian economy in a very simple manner. He has also explained the distributive implication to increase the consumption and reduction in poverty. He concludes that if we want favorable impact of reform on growth reforms must form part of a continuing agenda of our economic policies.

Herbert Stein (1956) in his paper explains the objectives of policies for economic growth and stability and several difference s between stability and growth in his paper. Both the studies are descriptive. Important thing is that most of the literature has been vested to criticize the policies rather suggesting the way-out of the problem. Therefore, it is important to assess the performance of the Indian economy. What is the pace and pattern of the growth of the Indian economy? How well the Indian economy has grown. Is there any capability with stability parameters? Is there any possibility of sustained high growth after achieving the stability? Therefore, it becomes important to check the performance of the Indian economy in the last decades. So there is need of empirical study to understand the causal relationship between growth and stability parameters.

\section{OBJECTIVES:}

The main objective of this paper is to find out the main cause of stability of growth in Indian economy.

1) To assess the performance of Indian Economy

2) To know the pace and patter of the growth of the India economy.

3) To understand the capability with stability parameters.

4) To suggest the remedial measures for the growth with stability

\section{Hypothesis:}

To reach out the abovementioned objectives the following null hypothesis has been stated.

1. There is no significant inverse relationship between growth and stability parameters.

2. There is no significant causality between growth and stability parameters.

\section{Trend in GDP and Stability Parameters}

India's growth rate of gross domestic production (GDP) has shown the positive movement in the post reform period. Economic growth of Indian economy has grown at an average rate of 8.3 per cent per annum during 200-2018 despite the crisis affecting year 2009. In the year $2000-01$ it was 4.1 per cent while during 2005-06 and 2007-08, the economy grew at an annual 9.4 per cent. But the growth rate of GDP has come down 6.6 per cent in 2017-18 and 5.6 per cent in 2017-18. It is reveals that Indian economy gets back to the high growth rate it had seen in 2005-06. After the post reform period it was higher level so far. In the year 2002-03 it was found lowest 3.9 percent in the post reform period.

Current account deficit (CAD) measure the deference between one countries inflows and outflows of the income and transfers among the residents and rest of the world, derived from the foreign trade of goods and services (fabris and kilibarda, 2008). It is one of the key indicators of economy health. India's current account always shows the deficit. Even though the Indian economy performing well in the post reform period. India's share in world export has grown up from 0.5 per cent in and 1.68 per cent in 2017-18. But the deficit on current account remains modest during the post reform period but it was recorded surplus in 2019-20 at 0.1 percent and in $2019-20$ at $0.3 \%$ respectively. It was -0.6 per cent of GDP in 2000-01 and -0.7 per cent of GDP in 2017-18. During 2001-02 to 2003-04 it was positive and moderate and rest of the period was not only continuously in deficit but also worst in situation in 2011-12 to 2012-13 (figure 1). But it was recorded surplus in 2019-20 at 0.1 percent and in 2019-20 at $0.3 \%$ respectively It is imperative that the export growth has 
to be maintained at a level and it is necessary to keep the CAD at 1.5 per cent of GDP

\section{Figure 1:Trend in growth rate of GDP and Stability Parameters}

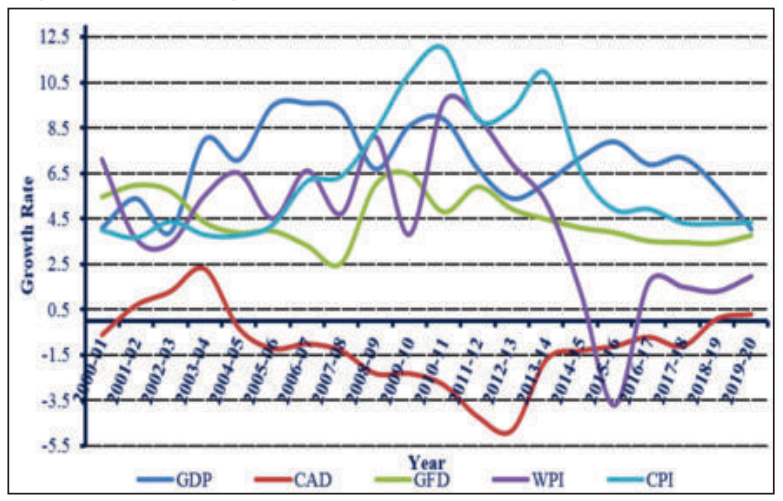

Gross fiscal deficit is the difference between the government's expenditure and its revenues. GFD means the excess of expenditure over receipts which is calculated as percentage of country's GDP. The pressure on the government's GFD is from the revenue side, particularly from tax-revenue receipts. The Government GST and direct tax revenue receipts are falling well short of its target. The FRBM Act has acted as a guide on GFD. After 2000-01, government seriously working on GFD, therefore since GFD has been a steadily decline. The India's GFD was 5.46 per cent of GDP in 2000-01, in 2008-09 and 2009-10 GFD stood at double the limit. In 2017-18 it almost come down near to the target at 3.1 per cent to the GDP (Chart 1). If India want to ensure the stability within it has to be confirm the fiscal discipline. But it was seems increases as 3.42 per cent in 2018-19 and 3.77 per cent in 2019-20.

Consumer price Index (CPI) is used to monitor changes in the cost of living over time. When CPI raises the average family living cost will increase to maintain their same standard of living. In the economic term is called as inflation. The new monetary policy framework are given more emphasis on the maintain to price stability within the country. 4 per cent inflation rate consider as reasonable and acceptable. In 200001 to 2005-06 and 2014-15 to 2017-18 CPI was in reasonable and acceptable area. But during 2006-07 to 2013-14 it shows the steady raises in CPI. While 2014-15 to 2019-20 it was fluctuating between 6.65 per cent to 3.30 per cent. Almost similar tendency is noted inWPI also (Chart 1 ).

\section{DATA AND METHODOLOGY:}

The data-set covers the period from 2001-2020 with all variables in a consent prices (2004-05) that are annual in nature and in logarithmic form. The macro level annual data has been taken from Handbook of Statistic, Reserve bank of India andWorld Bank data sources.

In this study, the analysis consists of five variables that would allow to link between growth and stability. There is no specific method used for selection of the variable. The selection of variable is purely based on underlying to the objectives of the study. The study deals with Annual growth rate of gross domestic production (GDP) and macro level parameters of stability i.e. current account deficit (CAD), gross fiscal deficit, (GFD) Wholesale price index (WPI) and consumer price (CPI) index. CAD, GFD, WPI and CPI are the predictor variables influencing on economic growth either positive/negative. To investigate the causal relationship between these five variables an econometric model has been framed and fitted. The least square model depicts the contribution of independent variables on dependent |www.worldwidejournals.com variables. This model is also easy to estimate and interpret.

To calculate regression between dependent and independent variable set a linear regression model. With the help of those models empirical results have been analyses.

\section{Model Specification}

The study is considered the least square regression model specified as follows;

$\log$ GDP $_{t}=\alpha_{1}+\beta_{2} \log \operatorname{CAD}_{\mathrm{t}-1}+\beta_{3} \log \mathrm{GFD}_{\mathrm{t}-1}+{ }_{4} \log \mathrm{WPI}_{\mathrm{t}-\mathrm{1}}+\beta_{\mathrm{f}} \log \mathrm{CPI}$ ${ }_{t-1}+\varepsilon_{\mathrm{t}}$

Where, $\log$ GDP is log of GDP, $\log C A D$ is $\log$ of CAD, logWPI is $\log$ of WPI and $\log C P I$ is $\log$ of CPI, $\varepsilon$ is the error term and $\alpha 0$ is the intercept. $\beta_{1}, \beta_{2}, \beta_{3}$ and $\beta_{4}$ are estimated coefficient of the GDP and stability parameters.

\section{EMPIRICAL RESULTS}

In all the result in this study, found that only the specification with one lag has the least AIC and SBIC Values, Mainly because our dta-set is quite small. Our results of Augmented Dickey-Fuller test show the table 2. CAD, GFDWPI and CPI are the stationary variable, with no unit root, al variables are integrated at first I(1) or second I(2) order difference so as to avoid spurious result (table 1).

Though all the five variables are stationary still examine the existence of cointegration among them. Results of Johansen Cointegration test have been summarized in Table 2. Since the trace-statistic is less than the critical value when rank $=1$ and greater than critical value when rank $=0$, the conclusion is that there is at least one cointegrating relationship among the variables considered herein.

The estimation shows that only 18 per cent of the fraction between the variable can be explained by the model used in the study. In the other words, rest of the variance on this model (GDP) was left uncounted and it was attributed to the error term. Overall this estimation was significant at a level of $5 \%$ significant level. Table 3 reveals that there is negative relationship between IWPI, ICAD , IGFD and IGDP while ICPI and IGDP shows the positive associationship among them. Estimation of model shows that an increase of 1 unit in the CPI in India will be increase in GDP by 40 per cent of explained variance on an average. But decrease of I unit in the lWPI, ICAD and IGFD will be increase in GDP of India 13\%, $22 \%$ and $8 \%$ respectively on an average. Thus consistent with the assumption of this study, stability parameters are the predictor of economic growth of India.

\section{CONCLUSION:}

Empirical result of the study shows that there is positive relationship between growth rate of GDP and the stability parameter. The results also show that CPI always positively affects on the growth rate of GDP, whereas WPI, CAD and GFD show that there is negative relationship with growth rate of GDP. So on an average four per cent inflation rate which is considerate reasonable and it found acceptable also. But as far as CAD and GFD is concern, there is need of that guidelines mention in the FRBA Act, has to be implement even more systematic and strict.The FRBM Acts guidelines must be the part of our new economic policy framework. But the government failure to frame the appropriate police to target the economic issues also found failed. Especially, Indian government seems to worry with the CAD and GFD, governments have been taken various initiatives to manage the fiscal consolidation, but most of the initiatives found useless. Thus, the government's economic policy adversely affects on the GDP growth rate. Therefore there should be a policy concern to give the boost to the economic growth of country. 
PARIPEX - INDIAN JOURNAL OF RESEARCH | Volume - 10 | Issue - 12 |December - 2021 | PRINT ISSN No. 2250 - 1991 | DOI : $10.36106 /$ paripex Table 1: Unit Roots Test/Augmented Dickey-Fuller (ADF) Test

\begin{tabular}{|c|c|c|c|c|c|c|c|c|c|c|}
\hline & \multicolumn{5}{|c|}{$\begin{array}{c}\text { Part A } \\
\text { With Constant only Sample period 1990-2017 }\end{array}$} & \multicolumn{5}{|c|}{$\begin{array}{c}\text { Part B } \\
\text { With Constant and Time Trend, Sample period 1990-2017 }\end{array}$} \\
\hline Variables & Lag Level $^{1}$ & $1 \%$ & $5 \%$ & $10 \%$ & Defference $^{1}$ & Lag Level $^{2}$ & $1 \%$ & $5 \%$ & $10 \%$ & Difference $^{2}$ \\
\hline (1GDP) & 1,1 & -4.571 & -3.690 & -3.286 & $-5.334 * * *$ & 1,1 & $-4 . .616$ & $-3 . .710$ & -3.297 & $-6.519 * * *$ \\
\hline (lCPI) & 1,1 & -4.571 & -3.690 & -3.286 & $-4.290 . * *$ & 1,1 & -4.667 & -3.733 & -3.310 & $-6.577 * * *$ \\
\hline (lWPI) & 1,1 & -3.286 & -3.690 & -4.571 & $-4.147 * *$ & 1,1 & -4.616 & -3.710 & -3.297 & $-6.768 * * *$ \\
\hline (ICAD) & 1,1 & -4.800 & -3.791 & -3.342 & $-3.393 *$ & 1,1 & -2.708 & -1.962 & -1.606 & $-2.727 * * *$ \\
\hline (IGFD) & 1,1 & -2.708 & -1.962 & -1.606 & $-5.119 * * *$ & 1,1 & -4.728 & -3.759 & -3.324 & $-6.827 * * *$ \\
\hline
\end{tabular}

$* * *, * *$ and * indicate level if significance $1 \%, 5 \%$ and $10 \%$ respectively.

Table 2:Johansen Cointegration Test Results

\begin{tabular}{|c|c|c|c|c|c|}
\hline $\begin{array}{c}\mathrm{H}_{0}: \text { no of } \\
\mathrm{CE}\end{array}$ & $\begin{array}{c}\text { Trace } \\
\text { Stat. }\end{array}$ & $\begin{array}{c}\text { Eigen } \\
\text { value }\end{array}$ & $\begin{array}{c}\text { Critical } \\
\text { Value 5\% }\end{array}$ & $\begin{array}{c}\text { Max } \\
\text { Stat. }\end{array}$ & $\begin{array}{c}\text { Critical } \\
\text { Value 5\% }\end{array}$ \\
\hline $\mathrm{R}=0$ & 70.16 & $0 . .081$ & $69.81 * * *$ & 29.64 & 33.87 \\
\hline $\mathrm{R}<1$ & 40.51 & 0.72 & 47.86 & 23.24 & 27.58 \\
\hline $\mathrm{R}<2$ & 17.26 & 0.45 & 29.79 & 10.94 & 21.13 \\
\hline $\mathrm{R}<3$ & 6.32 & 0.18 & 15.49 & 3.70 & 14.26 \\
\hline $\mathrm{R}<4$ & 2.61 & 0.13 & 3.84 & 2.61 & 3.84 \\
\hline
\end{tabular}

$* * *, * *$ and * indicate level if significance $1 \%, 5 \%$ and $10 \%$ respectively.

Table 3:Estimated Cointegrating Relationship

\begin{tabular}{|l|l|l|l|}
\hline Variable & Coefficient & Std. Error & t-statistic \\
\hline C & -0.128248 & 0.573977 & $-0.235760 * *$ \\
\hline $\mathrm{d}(\mathrm{lCPI})$ & 0.405437 & 0.306641 & 1.322188 \\
\hline $\mathrm{d}(\mathrm{lWPI})$ & -0.139206 & 0.165356 & -0.841856 \\
\hline $\mathrm{d}(\mathrm{lCAD})$ & -0.229554 & 0.180274 & -1.273356 \\
\hline $\mathrm{d}(\mathrm{lGFD})$ & -0.085977 & 0.331234 & -0.259595 \\
\hline R-squared & 0.362021 & Mean dependent var & 0.223235 \\
\hline $\begin{array}{l}\text { Adjusted R- } \\
\text { squared }\end{array}$ & 0.179741 & S.D. Dependent var & 2.441014 \\
\hline $\begin{array}{l}\text { S.E. of } \\
\text { Regression }\end{array}$ & 2.210781 & Akaike info criterion & 4.645503 \\
\hline $\begin{array}{l}\text { Sum squared } \\
\text { reside }\end{array}$ & 68.42573 & Schwarz criterion & 4.894039 \\
\hline F-Statistic & 1.986074 & Hannan-Quinn Criter. & 4.687565 \\
\hline Prob (F-Stat.) & 0.152030 & Durbin-Watson stat & 2.375617 \\
\hline
\end{tabular}

\section{REFERENCES:}

1. Fabris, N., Kilibarda B., Kalezic Z., Radunovic M. and Rakocevic M. (2008) Strane direktne investicije kao pokreta $\square$ privrednog razvoja Crne Gore, Central Bank of Montenegro,Working paper no. 16

2. Herbert Stein, (1956) Policies for Economic Growth and Stability,Journal of FarmEconomics Vol. 38, No. 5, Proceedings of the Annual Meeting of the American Farm Economic Association Meeting Jointly with the Western Farm Economics Association August 26-29, 1956, Asilomar, California (Dec., 1956), pp. 1159-1172

3. Rangrajan, C.(2018) Growth with Stability, unpublished Inaugural Address at $39^{\text {th }}$ Annual Conference of Association of Economists of Tamil Nadu held at Madras Christian college Chennai, on 21 December 2018.

4. Reserve Bank of India (2019) Handbook of Statistic, Reserve Bank of India

5. World BankDatabase 